\title{
Drinking Water Treatment in Submerged Hollow Fiber Microfiltration: Effect of Backwashing
}

\author{
Ergün Yildiz $^{1}$, Ibrahim Cengiz ${ }^{1}$, Arzu Kop ${ }^{1}$, Nejdet Degermenci ${ }^{2}$, Alper Nuhoglu' \\ ${ }^{1}$ Department of Environmental Engineering /Ataturk University \\ Engineering Faculty, Erzurum, Turkey \\ eyildiz@atauni.edu.tr; anuhoglu@atauni.edu.tr \\ ${ }^{2}$ Department of Environmental Engineering /Kastamonu University \\ Engineering and Architecture Faculty, Kastamonu, Turkey \\ degermenci@kastamonu.edu.tr
}

\section{Extended Abstract}

Water falling onto earth surface creates surface runoffs and while portion of precipitation seeps underground, water dissolves loads of substances from earth layers. Therefore chemistry of water constantly changes. Surface waters are very sensitive to contamination and cause of that water quality decreases over time. In recent years, need for clean water is increasing due to population growth and industrialization. Intensive industrialization and unplanned urbanization threaten water resources while conventional treatment systems are inadequate against increasing pollution

Membrane process (MP), has many advantages like less area requirement, high efficiency, easy operation and can be combined with conventional treatment systems. Therefore water treatment with MP is becoming popular. MP removes pathogens, decreases necessity for disinfection [1] and lowers the by-product formation in water treatment [2]. Additionally, MP has advantages like less chemical use and isn't effected from raw water properties [3]. In drinking water treatment MP is commonly used as external membrane filtration. External MP Processes provides higher flux but they get polluted more within shorter periods. Unlike external membranes submerged membranes support less flux and less pollution.

Purpose of this study, is to determine determining the effect of backwashing in treatment of drinking water of a dam with coagulation supported submerged PVDF hollow fiber (HF) filtration. In this way filtration mode which provides lesser pollution on membranes could be compared with conventional water treatment plant.

In this study, raw influent of drinking water plant in Erzurum was used. Experiments were carried out with lab-scale full automated submerged membrane filtration unit. COD and turbidity measurements were made for system effluent. Membrane $\Delta \mathrm{P}$ increases were noted while system was used in flux controlled mode. PVDF HF Membranes, which has 600 $\mathrm{cm}^{2}$ surface area and $0.4 \mu \mathrm{m}$ pore size, were used in the system and they were aerated with $5 \mathrm{~L} / \mathrm{min}$ air. First of all, optimum alum dosage was determined and same dosage was used in continuous system with backwashing or relaxation for all operation period. Membrane flux of $\mathrm{J}=20 \mathrm{~L} / \mathrm{m}^{2} . h$ was kept constant and two different membrane cleaning methods were used. These are filtration + relaxation and filtration + backwashing. While filtration periods were 4.5, 9 and 18 min, relaxation and backwashing periods were selected as $0.5,1$ and 2 mins respectively. Backwashing flows were selected same as filtration flux.

$10,20,30,40,60,80$ and $100 \mathrm{mg} / \mathrm{L}$ alum dosages were used. Even with the minimum dosage of $10 \mathrm{mg} / \mathrm{L}$ alum, Coagulation + HF submerged membrane system provides water suitable for Turkey drinking water standards. The same water quality is reached at $40 \mathrm{mg} / \mathrm{L}$ alum dosage by conventional treatment system, which shows the superiority of membrane treatment systems again. Effluent turbidity values were found as $0.02 \mathrm{NTU}$. COD removal efficiency was increased up to $\% 90$ with increasing alum dosage. Effluent turbidity, TOC, TN and $\mathrm{UV}_{254}$ removal ratios were calculated as \%99.8, \%37, $\% 43$ and $\% 40$ respectively when the minimum dosage of $10 \mathrm{mg} / \mathrm{L}$ alum was applied.

In continuous experiments with $4.5 \mathrm{~min}$ filtration $+0.5 \mathrm{~min}$ relaxation, $\Delta \mathrm{P}$ pressure increase in $48 \mathrm{~h}$ period was $\% 26$ while $4.5 \mathrm{~min}$ filtration $+0.5 \mathrm{~min}$ backwashing mode resulted $\% 5$ increase in $\Delta \mathrm{P}$. Under these conditions, effluent turbidity value increased from $0.02 \mathrm{NTU}$ to only $0.06 \mathrm{NTU}$. In $9+1$ mode with relaxation $\Delta \mathrm{P}$ increase was $\% 27$ while same mode with backwashing decreased the $\Delta \mathrm{P}$ to $\% 14$. In same manner, 18+2 mode with backwashing decreased $\Delta \mathrm{P}$ from $\% 29$ to $\% 22$. 
As a result coagulation $+\mathrm{HF}$ submerged membrane system provides better water quality with less alum than conventional drinking water treatment systems. $J=40 \mathrm{~L} / \mathrm{m}^{2} \mathrm{~h}$ flux value was reached in experiments and less membrane pollution was obtained which created a system comparable to external membranes. In addition, frequent backwashing was found to be a suitable strategy against membrane pollution.

\section{References}

[1] S. Sridang, A. Grasmick, and U. Puetpaiboon, "Influence of water compositions and conditioning on flux enhancement in an immersed membrane system," Separation Science and Technology, vol. 43, pp. 1813-1825. 2008.

[2] N. F. Gray, "Drinking Water Quality, Second Edition," Published in the United States of America by Cambridge University Press, New York. Guo, 2008.

[3] G. Capannelli, "Emerging wastewater treatment and water sanitation technologies: membrane application in this field", in Technologies for Soil and Water Remediation and for POPs Destruction," Trieste, 2005. 